\title{
Economic Drivers of Legume Production: Approached via Opportunity Costs and Transaction Costs
}

\author{
Julia Jouan ${ }^{1, *(D)}$, Aude Ridier ${ }^{1}(1)$ and Matthieu Carof ${ }^{2}$ (D) \\ 1 SMART-LERECO, AGROCAMPUS OUEST, INRA, 35000 Rennes, France; aude.ridier@agrocampus-ouest.fr \\ 2 SAS, AGROCAMPUS OUEST, INRA, 35000 Rennes, France; matthieu.carof@agrocampus-ouest.fr \\ * Correspondence: julia.jouan@agrocampus-ouest.fr; Tel.: +33-(0)2-2348-5482
}

Received: 21 December 2018; Accepted: 26 January 2019; Published: 29 January 2019

\begin{abstract}
Crop diversification is one of the main mechanisms identified for developing a more sustainable agriculture. Legumes are interesting diversifying crops to add to crop rotations because of their many positive impacts on agronomic systems. Nonetheless, production of these crops remains relatively low in Europe, in part because of socio-economic factors. The objective of this study was to analyze how the economic attractiveness of legumes may be influenced by two factors: opportunity costs and transaction costs. The method is divided into three steps. First, we built a database of opportunity costs of legumes from a literature review. Second, we qualitatively characterized transaction costs associated with exchange of legumes between producers and collectors. Third, we qualitatively analyzed if contracts currently offered in western France decreased transaction costs. For comparison, transaction costs of linseed were also studied. Our results indicate that legumes are economically attractive at the rotation scale due to zero or negative opportunity costs, but that their transaction costs are high. The contracts studied do not decrease these transaction costs sufficiently, in particular because uncertainties in price remain high in half of these contracts. Downstream differentiation seems necessary to decrease transaction costs by creating added value along the entire agro-food chain.
\end{abstract}

Keywords: contract; gross margin; protein crops; linseed; western France

\section{Introduction}

Crop diversification is one of the main mechanisms identified for developing a more sustainable agriculture [1]. Many positive impacts on agronomic systems are associated with it: improving biodiversity [2], increasing resilience of agronomic systems [3,4] and decreasing the use of pesticides [5,6]. Legumes, both grain legumes (pea, faba bean, lupin, soybean) and forage legumes (alfalfa, white clover, red clover), are interesting diversifying crops to add to crop rotations [7]. Unlike other crops, legumes can fix atmospheric nitrogen; thus, they need no nitrogen fertilization. Under certain conditions, legumes can also supply nitrogen to the soil, thus decreasing application of nitrogen inputs for the subsequent crop, or even increasing its yield [8]. In addition to their ability to fix nitrogen, legumes also have the interesting agronomic characteristics of breaking weed cycles and improving soil structure [9]. The issue of support for legumes (and oilseed crops) is particularly striking in the European Union (EU) since the Blair House agreement of 1992, which has led to a decrease in their production there. In 2014, the EU enabled its member states to establish area-based subsidies for legumes, such as supports coupled to production and green payments related to the presence of legumes on a farm, without any production target. These recent measures have reversed the decreasing trend, and the area of grain legumes, including soybean, increased by $75 \%$ from 2013-2017 [10]. Nonetheless, production of grain legumes remains low, covering only $2 \%$ of utilized agricultural area in the EU in 2017 (4\% if including forage legumes) [10]. 
Other economic factors, which differ according to the scale of action in which they appear and according to their nature, can explain this situation [11]. The scale of action can be the farm, where production occurs, but also the agri-food chain, where problems of processing or lack of markets can appear, thus limiting demand for the producer. Regarding nature, economic factors can be identified as opportunity costs of legumes, which reflect their economic attractiveness compared to other crops already produced or marketed. In contrast, other economic factors have to do with other types of costs, which are difficult or impossible to quantify, related to asymmetric information about new crops and uncertainty during their production and marketing. These indirect costs include transaction costs [12].

First, for opportunity cost at the farm scale, farmers often consider legumes as less profitable in the short term than other more common crops on the farm (e.g., wheat, rapeseed) [13], even though this assessment must be balanced in certain cases (e.g., organic farming) [14] or in areas with a climate more favorable to these types of production. In contrast, at the rotation scale, if one considers the decreased inputs (e.g., nitrogen fertilizers) and/or increased yields of subsequent crops, the profitability can be increased. In addition, legumes are considered riskier than more common crops because of their more variable yields from year to year, though there is no consensus on this characteristic in the scientific community [15,16]. Because of farmers' risk aversion [13], legume margins are penalized with a higher risk premium (i.e., the amount of money that a farmer is willing to pay to eliminate all risk) than those of other crops, which decreases their relative profitability even more. Finally, for opportunity costs at the scale of processing industries, the lack of added value and of differentiation in the legume agro-food chain can penalize legume production; for example, in the animal feed market, legumes are easily replaced by other, less expensive raw materials, which greatly decreases their inclusion in rations [17].

For indirect costs at the agro-food chain scale, certain authors note that legume production has not developed due to a "lock-in" situation, previously analyzed for other sectors in the economics of innovation [18]. For the agricultural sector, this lock-in appears to result from a co-evolution of markets, agrochemical companies and public policies that tends to favor cereal and oilseed crop agro-food chains $[19,20]$. Today, this hegemony of a few cereal and oilseed crops limits development of diversifying crops such as legumes, since cooperatives and companies have not developed sufficient logistics or technical skills to produce them at a large scale. Large transaction costs can thus appear during exchanges. The theory of transaction costs, introduced by Coase in "The nature of the firm" [12] and then theorized by Williamson [21], explains that these costs are related to the search for information, the process of negotiation and verifications before and after the transaction. The higher the transaction costs, the more actors are inclined to choose an integrated mode of coordination. Different modes of coordination have been described, ranging from "market" to "hierarchy" (in which transactions occur in an integrated manner). Contracting is a "hybrid" mode of coordination between market and hierarchy that aims to decrease transaction costs related to the exchange of new crops such as legumes [22,23]. Many empirical studies have been performed on contracting in the agricultural sector, on both animal and plant production [24-27], but few of them have focused on contracting in the legume agro-food chain. In the study [28], production contracts for field crops were analyzed between cooperatives and their members, some of whom produced legumes. They showed that these contracts can incite farmers to diversify their crops by offering an attractive payment system and that collecting these new crops requires specific investments by cooperatives. Nonetheless, their study did not focus specifically on the diversity of contracts within the legume agro-food chain.

The objective of the present study was to analyze how the economic attractiveness of legumes to farmers may be influenced by two factors: opportunity costs and transaction costs. Our first hypothesis was that transaction costs decrease the economic attractiveness of legumes the most, due to characteristics specific to exchanges of these crops. Our second hypothesis was that contracting can decrease transaction costs and thus promote an increase in legume production. The main conclusions are that legumes are economically attractive at the rotation scale, but that their transaction costs are 
high. The contracts studied do not decrease these transaction costs sufficiently, in particular because uncertainties in price remain high in half of these contracts.

\section{Materials and Methods}

\subsection{Analysis of Opportunity Costs of Crops}

Opportunity cost is defined as the net benefits of the next best alternative that are forgone when a specific activity is chosen. It can be expressed as the difference between the net benefits of the next best alternative and those of the chosen alternative [29]. We calculated the opportunity cost of a legume as the margin of the crop it replaced (a cereal or oilseed crop, which represents the next best alternative), minus the margin of the legume (i.e., the chosen alternative). Therefore, if the opportunity cost of the legume is negative, the legume is preferable. Different types of margin can be used in the calculation. Gross margin considers the revenue from selling the crop minus the variable costs of inputs (seeds, fertilizers and pesticides). In accounting rules, coupled support can also be included in revenue, yielding "gross margin with subsidies". Other margin indicators also include additional costs, such as the machinery or labor directly related to the crop, yielding the "semi-net margin" or "gross margin after machinery costs". Likewise, margins can be calculated at the scale of a crop or a crop rotation. In the latter case, the rotation margin is estimated as the average of the margins of each crop in the rotation. One calculates average annual gross margin from the gross margins earned over several years, usually without considering a depreciation of capital costs. This approach is particularly useful for rotations in which certain crops provide agronomic benefits to others, as occurs for rotations with legumes. Finally, margins can be calculated in two ways. In the first, a margin can be defined a priori by including in the calculation the yields, prices, and costs available in databases of public statistics and agricultural organizations. It is a difficult approach, however, since these data vary among regions and years and are not necessarily published (especially costs of a given crop). In the second way, a margin can be defined a posteriori by including in the calculation observed accounting information: revenue from selling crops and costs of crops. However, these accounting data often remain confidential. The analytical breakdown of revenue and costs is also specific to each farm and is not performed the same way for all farm accounts, which often stop at the scale of the farm or the subsystem [30].

A database of opportunity costs of legumes was built from a literature review. To do this, we searched for pairs of keywords formed from a crop ("legume", "protein crop", "pea", "lupin", "soybean", "faba bean", "alfalfa" and "lucerne") and an economic term ("gross margin", "profitability" and "profit") in the databases of the Web of Science, Google Scholar and Google. This search was also performed using the same pairs of keywords in French. Depending on the article analyzed, we calculated opportunity costs of legumes from gross margins at the scale of the crop or the rotation, either a priori or a posteriori.

\subsection{Analysis of Transaction Costs}

\subsubsection{Surveys of Collectors of Legumes or Linseed}

Farmers who produce and market legumes may, in addition to production costs, pay transaction costs related to marketing. To assess the level of these transaction costs, we surveyed five organizations in western France (Brittany and Pays de la Loire): four cooperatives (A to D) that collect and market one or more legumes and, for comparison, Collector E, which has developed a local market for linseed for animal feed (Table 1). Since linseed and legumes have many characteristics in common [31], we compared the mature market of linseed with the budding markets of legumes. Four legumes under contract were studied: the two main legumes produced in the region (i.e., pea and alfalfa) and two others that are less developed. To simplify the analysis, we present results for only one crop per organization (hereafter, "collector") (Table 1). Collector E does not collect linseed directly but rather 
uses an intermediary for collecting. Semi-directed interviews of one hour were performed over three months and covered (i) the legumes (or linseed) collected and the contracts offered; (ii) management of uncertainties in volume (i.e., lower yield than expected), price and quality; and (iii) marketing of and markets for the contracted products.

Table 1. Collectors surveyed that collect legumes or linseed. Bold text indicates the crop analyzed for each collector.

\begin{tabular}{|c|c|c|c|}
\hline Collector & Size & Product & Activities \\
\hline $\mathrm{A}$ & 1000 members & $\begin{array}{l}\text { Dehydrated alfalfa } \\
\left(90,000 \text { t. }^{-1} \mathrm{r}^{-1}\right)\end{array}$ & $\begin{array}{l}\text { Advice, supply, harvest, transport, } \\
\text { alfalfa dehydrating, marketing }\end{array}$ \\
\hline B & 4000 members & Faba bean (1800 t.yr $\left.{ }^{-1}\right)$ & $\begin{array}{l}\text { Advice, collection, production and } \\
\text { marketing of animal feed }\end{array}$ \\
\hline $\mathrm{C}$ & 16,000 members & $\begin{array}{l}\text { Pea }\left(2000 \text { t.yr }{ }^{-1}\right) \\
\text { Faba bean, Lupin }\end{array}$ & Advice, collection, marketing \\
\hline $\mathrm{D}$ & 29,000 members & $\begin{array}{c}\text { Lupin }\left(3000 \text { t.yr }^{-1}\right) \\
\text { Faba bean, Pea }\end{array}$ & Advice, collection, marketing \\
\hline $\mathrm{E}$ & 120 employees & $\begin{array}{c}\text { Linseed }\left(60,000 \text { t.yr }{ }^{-1}\right), \\
\text { Faba bean }\end{array}$ & $\begin{array}{l}\text { Processing, link between } \\
\text { producers and processors }\end{array}$ \\
\hline
\end{tabular}

\subsubsection{Analysis of Asset Specificity and Uncertainties During Transactions}

To characterize the transaction costs associated with the exchange of legumes (or linseed), we developed an analysis framework based on the theory of transaction costs. In the approach of Williamson [32], transaction costs depend on three characteristics of the transaction: the specificity of the assets invested during it, the uncertainty surrounding it and its frequency.

We studied different types of asset specificity during legume (or linseed) transactions : (i) human assets, which depend on the specific knowledge and know-how (of both the producer and the collector) used to produce and process the crops; (ii) the material assets, which depend on the specific investments of both the producer and collector; and (iii) the location of the collection zone, if it is limited, which also entails specific investment costs. This information came from interviews with employees of the collectors. Regarding uncertainties surrounding transactions, there are four main types: (i) uncertainties in volume due to potentially low yield of the crop collected, (ii) uncertainties in quality due to potentially low protein contents, (iii) uncertainties in prices due to a potential decrease in prices of crops and (iv) uncertainties in the markets for crops. These uncertainties were assessed from literature data on yields [15], statistical data on crude protein contents [33-35] and on prices [36-38] from 2013-2017, and interviews to obtain information about markets. We qualitatively assessed uncertainties during transactions, as well as asset specificity, as "low", "moderate" or "high" compared to those of wheat. Regarding transaction frequency, transactions occur during every growing season; so, we did not study it as an attribute specific to legumes (or linseed).

\subsubsection{Analysis of the Effectiveness of Contracts at Decreasing Transaction Costs}

To determine whether contracting effectively decreased transaction costs during exchanges of legumes (or linseed), we developed an analysis framework of the variety of legume contracts offered by the collectors surveyed. Two types of contracts were analyzed: marketing contracts, which specify only selling conditions (e.g., methods for determining prices and amounts, as well as delivery dates and methods), and production contracts, which also specify at least one of the agricultural practices used, to influence the final quality of the product [39]. When a given collector offered different types of contracts for a given crop, only the production contract was studied because, being more comprehensive, it is more likely to reduce transaction costs. The analysis framework began with the characteristics of transaction costs without a contract and then studied how the contracts modified these characteristics (i.e., whether the contracts decreased the uncertainties examined and secured the specific asset). As for the characteristics of transaction costs, we qualitatively analyzed their variations. 


\section{Results}

Many recent literature reviews examined agronomic and environmental performances of legumes [15,40-42]. Nonetheless, few studies focused on legumes from an economic angle [43]. In particular, few data or scientific studies exist on the economic attractiveness of legumes, even though the issue of their opportunity costs remains a priority for farmers when choosing which crops to plant.

\subsection{Opportunity Costs of Legumes}

\subsubsection{Opportunity Costs of Legumes: Annual Approach to the Cropping System}

The database from the literature review [44] showed that the opportunity costs of legumes that replaced wheat (hereafter "legume-wheat") were positive in 10 of the 12 case studies studied (i.e., mean annual a priori gross margins were lower than those of wheat). More recently, compared to an a priori gross margin of wheat, the a priori gross margin of pea was estimated to be $56 \%$ lower in southwestern France [45], while another study estimated those of pea, lupin and faba bean in Brittany to be $50 \%$ lower [14]. Therefore, legume-wheat opportunity costs in these studies were positive. It is interesting to note that this last study observed better economic performances of legumes in organic farming systems. For example, the a priori gross margin of organic faba bean reached $800 €$.ha $^{-1}$, nearly double that of conventional faba bean. Nonetheless, the difference in gross margin between organic pea and organic wheat remained large, which resulted in positive opportunity costs. From the data used in the study [46], we calculated a posteriori gross margins of legumes and wheat. These data confirm results of a priori studies: they reveal a positive legume-wheat opportunity cost, with the a posteriori gross margin of grain legumes being $46 \%$ lower than that of wheat. However, it is more relevant from an agronomic viewpoint to calculate opportunity costs between legumes and other potential head-of-rotation crops (i.e., a crop planted in the first year of a rotation because its agronomic characteristics benefit subsequent crops) such as canola [44]. In the review [44], legume-canola opportunity costs were positive in 11 of 12 case studies studied. Likewise, positive opportunity costs were observed, with a priori gross margins of lupin and pea ca. $66 \%$ lower than those of canola [47].

\subsubsection{Opportunity Costs of Legumes: Multi-Annual Approach to the Cropping System}

Studying the opportunity cost of a rotation with legumes compared to one without legumes (hereafter, "with/without opportunity cost") is much more relevant: doing so accounts for the fact that legumes fix atmospheric nitrogen, which may lead to decreased application of nitrogen inputs for the subsequent crop, or even increases in its yield. Rotations with legumes generally have zero or even negative opportunity costs, with gross margins similar to or even greater than those of rotations without legumes. In the review in Reference [44], with/without opportunity costs were close to zero for 35 of 53 rotations with legumes modeled a priori. This confirms an initial study in east-central France of rotations with canola, wheat and barley (over 3-4 years) [48]. Results of this study indicated that all but one rotation with pea had a priori gross margins that were similar to or higher than those without pea (0-6\% higher). More recently, another study showed that with/without opportunity costs of grain legumes were slightly positive, while those of forage legumes were zero or even negative, with a priori gross margins that were similar or slightly higher [49]. Of the five studies we found of opportunity costs of rotations with legumes, only two analyzed the with/without opportunity cost of a forage legume $[49,50]$. The with/without opportunity cost of alfalfa was nearly zero, since the difference in a priori gross margin between rotations was low [50]. This lack of visibility of the profitability of forage legumes can be explained by the fact that they are rarely sold, which prevents gross margins from being calculated. In the study [44], the gross margins of wheat and canola were calculated when they were included in rotations with legumes in southern Australia: a priori gross margins of the two crops in rotations with legumes were higher than those in rotations without legumes, as long as nitrogen fertilization was less than $75 \mathrm{~kg} \mathrm{~N} . \mathrm{ha}^{-1}$. In another study, a potential increase in gross margin of $118 € . \mathrm{ha}^{-1}$ was estimated for conventional rotations with grain legumes compared 
to those without [14]. Finally, compared rotations with/without grain legumes were compared in three European regions [51]. It was observed that rotations with grain legumes have slightly higher a priori gross margins than rotations with no legumes and $75 \%$ or more cereals. Therefore, in this study, rotations with grain legumes were characterized by negative with/without opportunity costs.

The economic incentive for growing legumes is closely related to their head-of-rotation function: they have a zero or negative opportunity cost only when studied at the scale of the rotation. Legumes thus do not degrade the competitiveness of farms in the middle term and, in addition, have other beneficial effects on the environment that are not included in the market (e.g., improvement of biodiversity and water quality).

\subsubsection{Opportunity Cost of Legumes: Multi-Annual Approach in Mixed Crop-Livestock Systems}

The economic attractiveness of legumes can also be understood at a scale more encompassing than that of a rotation. In mixed crop-livestock systems, farmers can choose not to sell legumes, instead using them to feed animals on the farm. They thus replace other types of animal feed, and the opportunity cost of these feeds can be studied [52,53]. Nonetheless, few studies have focused on economic consequences of these practices [54]. Mathematical programming models are useful tools for assessing impacts of introducing legumes into rations because they allow activities to compete based on the opportunity cost of the set of all production factors. To our knowledge, no model has focused specifically on the use of legumes except for the study [55], which aimed to analyze consequences of introducing legumes onto mixed crop-livestock farms, from both economic and environmental viewpoints.

\subsection{Transaction Costs and Organizational Choice: Case Studies in Western France}

\subsubsection{Transaction Costs of Exchanging Legumes and Linseed}

Asset specificity during legume transactions was usually higher than those of main crops of the region, such as wheat (Table 2). First, the specificity of human assets involved was moderate for the producers but could be high for certain collectors who establish procedures for processing legumes, such as Collectors A and D. Similarly, the specificity of physical assets was low for producers, who do not need to keep specific equipment to produce legumes (or linseed). In contrast, collectors must often adapt their storage capacities, even more so if they sort products by quality. Collectors who established procedures for processing legumes also had high specificity of physical assets, given that investment in equipment is often necessary for processing. Finally, the specificity of location was particularly high for Collector A, whose collection zone for alfalfa is restricted to a $70 \mathrm{~km}$ radius around its dehydration factory due to logistical constraints.

Uncertainties during transactions of legumes (or linseed) were moderate to high compared to those of main crops of the region, such as wheat (Table 3). First, volume uncertainties were particularly high for lupin, which had a standard deviation of yield anomalies (i.e., normalized yield residuals) of 0.32 , much higher than that of wheat (0.06) ([13]). We found no data for the variability of alfalfa or linseed yields. Second, regarding variability in the quality of the crops studied, we found no specific data for alfalfa or lupin, but it appeared during the interviews that variability in crude protein contents was not considered a problem. However, according to our calculations, quality uncertainties were high for faba bean and linseed, which had a coefficient of variation (CV) of crude protein content of 0.028 and 0.036 , respectively, compared to that of wheat $(0.013)$. Quality uncertainties for pea were similar to those of wheat. Third, according to our calculations, price uncertainties were particularly high for faba bean, which had a CV of selling price of 0.221 from 2013-2017, compared to that of wheat (0.155). For other crops, price uncertainties were lower than those of wheat, with pea and linseed even having $\mathrm{CVs}$ of selling price less than 0.1. Finally, market uncertainties for crops were low for alfalfa and pea, which are used in many feeds. Market uncertainties were greater for linseed, which depends on the Bleu-Blanc-Cœur market. The highest market uncertainties were for faba beans, which depend greatly on the Egyptian market, and lupin, which remains a niche market. 
Table 2. Analysis of the degree of asset specificity (high, moderate, low) during transactions of legumes and linseed of the five collectors surveyed, compared to those of wheat, except where noted. Data and assessments come from interviews performed during the study, except where noted.

\begin{tabular}{|c|c|c|c|c|c|c|}
\hline \multicolumn{2}{|c|}{ Asset Specificity } & $\begin{array}{c}\text { A } \\
\text { Alfalfa }\end{array}$ & $\begin{array}{c}\text { B } \\
\text { Faba Bean }\end{array}$ & $\begin{array}{c}\text { C } \\
\text { Pea }\end{array}$ & $\begin{array}{c}\text { D } \\
\text { Lupin }\end{array}$ & $\begin{array}{c}\text { E } \\
\text { Linseed }\end{array}$ \\
\hline $\begin{array}{l}\text { Human } \\
\text { assets }\end{array}$ & $\begin{array}{l}\text { For the } \\
\text { producer }\end{array}$ & \multicolumn{5}{|c|}{$\begin{array}{c}\text { Moderate } \\
\text { ming practices, less well known but not particularly difficult }\end{array}$} \\
\hline $\begin{array}{l}\text { Human } \\
\text { assets }\end{array}$ & $\begin{array}{l}\text { For the } \\
\text { collector }\end{array}$ & $\begin{array}{c}\text { High } \\
\text { Dehydration } \\
\text { technique and } \\
\text { technicians specific } \\
\text { to alfalfa }\end{array}$ & $\begin{array}{l}\text { Moderate } \\
\text { Training of } \\
\text { personnel to } \\
\text { recognize the } \\
\text { cleanliness of a field }\end{array}$ & $\begin{array}{c}\text { Low } \\
\text { No specific } \\
\text { advice or } \\
\text { process }\end{array}$ & $\begin{array}{c}\text { High } \\
\text { Several techniques } \\
\text { for processing } \\
\text { lupin for } \\
\text { agro-food and } \\
\text { cosmetic uses }\end{array}$ & $\begin{array}{c}\text { High } \\
\text { Thermo-extrusion } \\
\text { of linseed for } \\
\text { animal feed and } \\
\text { human food }\end{array}$ \\
\hline $\begin{array}{l}\text { Physical } \\
\text { assets }\end{array}$ & $\begin{array}{l}\text { For the } \\
\text { producer }\end{array}$ & \multicolumn{5}{|c|}{ No specific equipment absolutely necessary } \\
\hline $\begin{array}{c}\text { Physical } \\
\text { assets }\end{array}$ & $\begin{array}{l}\text { For the } \\
\text { collector }\end{array}$ & $\begin{array}{c}\text { High } \\
\text { Harvest equipment } \\
\text { and } \\
\text { dehydration } \\
\text { equipment }\end{array}$ & $\begin{array}{c}\text { Moderate } \\
\text { Suitable storage } \\
\text { capacity }\end{array}$ & $\begin{array}{l}\text { Moderate } \\
\text { Suitable } \\
\text { storage } \\
\text { capacity }\end{array}$ & $\begin{array}{l}\text { High } \\
\text { Two processing } \\
\text { sites partly } \\
\text { dedicated to lupin; } \\
\text { suitable storage } \\
\text { capacity }\end{array}$ & $\begin{array}{c}\text { High } \\
\text { Many silos to } \\
\text { separate crops of } \\
\text { differing quality; } \\
\text { processing } \\
\text { equipment }\end{array}$ \\
\hline Location & $\begin{array}{l}\text { For the } \\
\text { producer }\end{array}$ & $\begin{array}{c}\text { High } \\
70 \mathrm{~km} \text { around the } \\
\text { dehydration factory }\end{array}$ & & No z & e specified & \\
\hline
\end{tabular}

Table 3. Analysis of the level of uncertainties (high, moderate, low) during transactions of legumes or linseed by the five collectors surveyed (A-E), compared to those of wheat.

\begin{tabular}{|c|c|c|c|c|c|c|}
\hline \multicolumn{2}{|c|}{$\begin{array}{l}\text { Uncertainties during } \\
\text { Transactions } \\
\text { Outside of Contracts }\end{array}$} & $\begin{array}{c}\text { A } \\
\text { Alfalfa }\end{array}$ & $\begin{array}{c}\text { B } \\
\text { Faba Bean } \\
\end{array}$ & $\begin{array}{c}\text { C } \\
\text { Pea }\end{array}$ & $\begin{array}{c}\text { D } \\
\text { Lupin } \\
\end{array}$ & $\begin{array}{c}\text { E } \\
\text { Linseed }\end{array}$ \\
\hline Volume & $\begin{array}{c}\text { For the } \\
\text { producer } \\
\text { and collector }\end{array}$ & No data & $\begin{array}{c}\text { Moderate } \\
\mathrm{SD}^{\mathrm{a}} \text { of yield } \\
\text { anomalies = } \\
0.09\end{array}$ & $\begin{array}{c}\text { High } \\
\text { SD of yield } \\
\text { anomalies = } \\
0.12\end{array}$ & $\begin{array}{c}\text { High } \\
\text { SD of yield } \\
\text { anomalies = } \\
0.32\end{array}$ & No data \\
\hline Quality & $\begin{array}{l}\text { For the } \\
\text { collector }\end{array}$ & No data & $\begin{array}{c}\text { High } \\
\mathrm{CVq}^{\mathrm{b}}= \\
0.028\end{array}$ & $\begin{array}{c}\text { Moderate } \\
\mathrm{CVq}=0.013\end{array}$ & No data & $\begin{array}{c}\text { High } \\
\mathrm{CVq}=0.036\end{array}$ \\
\hline Price & $\begin{array}{l}\text { For the } \\
\text { producer } \\
\text { and collector }\end{array}$ & $\begin{array}{c}\text { Moderate } \\
\mathrm{CVp}^{\mathrm{c}}= \\
0.113\end{array}$ & $\begin{array}{c}\text { High } \\
C V p=0.221\end{array}$ & $\begin{array}{c}\text { Moderate } \\
\mathrm{CVp}=0.093\end{array}$ & No data & $\begin{array}{c}\text { Low } \\
\mathrm{CVp}=0.066\end{array}$ \\
\hline Markets & $\begin{array}{l}\text { For the } \\
\text { collector }\end{array}$ & $\begin{array}{c}\text { Low } \\
\text { Used in } \\
\text { many animal } \\
\text { feeds }\end{array}$ & $\begin{array}{c}\text { High } \\
\text { Dependent } \\
\text { on exports to } \\
\text { Egypt }\end{array}$ & $\begin{array}{c}\text { Low } \\
\text { Used in } \\
\text { many animal } \\
\text { feeds }\end{array}$ & $\begin{array}{c}\text { High } \\
\text { Niche } \\
\text { market; lack } \\
\text { of visibility }\end{array}$ & $\begin{array}{c}\text { Moderate } \\
\text { Relatively } \\
\text { dependent } \\
\text { on the BBC } \\
\text { market }\end{array}$ \\
\hline
\end{tabular}

Note: a Standard deviations of yield anomalies for Western Europe from Reference [15], with that of wheat $=0.06$.

${ }^{\mathrm{b}}$ Coefficient of variation of quality $(\mathrm{CVq})$, measured as the variation in crude protein contents, with that of wheat

$=0.113$; calculation by authors based on data from References [33,34] for faba bean and pea, and from Reference [35] for linseed (2013-2017). ${ }^{\mathrm{C}}$ Coefficient of variation of price (CVp), measured as by the variation in prices outside of contracts, with that of wheat $=0.155$; calculation by the authors based on price data from References $[37,38]$ for alfalfa, faba bean and pea, and from Reference [36] for linseed (2013-2017). Only the CV of faba bean and linseed differed significantly from that of wheat (Levene's and Fligner-Killeen tests). ${ }^{\mathrm{c}}$ Bleu-Blanc-Cœur: production methods to improve food quality and agricultural sustainability.

Therefore, from analysis of the interviews, legume exchanges appear to have higher transaction costs than those of wheat, due to high asset specificity and high uncertainties. Producers would thus be inclined to choose a mode of organization that is more integrated than the market in order to decrease transaction costs.

Based on these results, we tightened our second hypothesis focused our second hypothesis: contracts decrease transaction costs by (i) decreasing volume and price uncertainties and (ii) securing the specific assets, in which mainly collectors have invested. Evidence supporting this hypothesis is 
strengthened by the fact that most collection of linseed, which has characteristics similar to those of legumes, is already contracted before harvest.

3.2.2. Effectiveness of Contracts at Decreasing Transaction Costs Related to Exchange of Legumes or Linseed

Analysis of legume contracts implemented by the collectors surveyed revealed great diversity: two of the collectors offered marketing contracts with an area or volume commitment, while the three others offered production contracts (Table 4). We examined whether these contracts supported our tightened second hypothesis.

Volume uncertainties were slightly decreased, for both producers and collectors, by contracts of Collectors B, D and E, whose technical monitoring limits variations in yields. In contrast, price uncertainties remained unchanged for collectors but were slightly decreased for producers by the contract of Collector $C$, which guarantees a price complement of $8 € \cdot \mathrm{t}^{-1}$, albeit based on a price fixed at harvest. The contracts of Collectors B, and D decreased price uncertainties for producers even more by guaranteeing a given gross margin (Collector B) or a fixed price before harvest (Collector D). This difference is related to the internal structures of the collectors (e.g., mutualizing risk among several products) and to contracts negotiated downstream, for which we had no information. Collector E offered a contract with a price "tunnel" that limits both positive and negative variation in prices. This greater decrease in price uncertainties is possible because Collector E directly marketed downstream the products from animals fed linseed in the Bleu-Blanc-Cœur market, in which nutritional qualities (omega-3 and -6 contents) of these products are recognized by consumers. Regarding market uncertainties for the collectors, they remained unchanged: the contracts do not secure their downstream markets.

Collector A decreased quality uncertainties by expecting a minimum crude protein content but did not appear to apply a penalty if it is not reached. Collector E had a bonus/penalty policy as a function of the content of certain fatty acids. In contrast, Collectors B, C and D did not calculate their payments for legumes as a function of quality. As for all field crops, standards of cleanliness and moisture content were expected for legumes. If they were not met, additional costs for drying could be billed to producers (Collectors B and C) or the crop could be refused (Collector D). Finally, securing of human and physical assets was related to a decrease in volume uncertainties: the more the contract decreased volume uncertainties, the more the collector's investments in producing and/or transforming legumes (or linseed) were secured. Therefore, human and physical assets were slightly secured for Collectors B, C, D and E. 
Table 4. Analysis of the evolution of transaction costs of legumes and linseed contracts (unchanged, slightly decreased, decreased), compared to those outside contracts, for the five collectors surveyed (A-E).

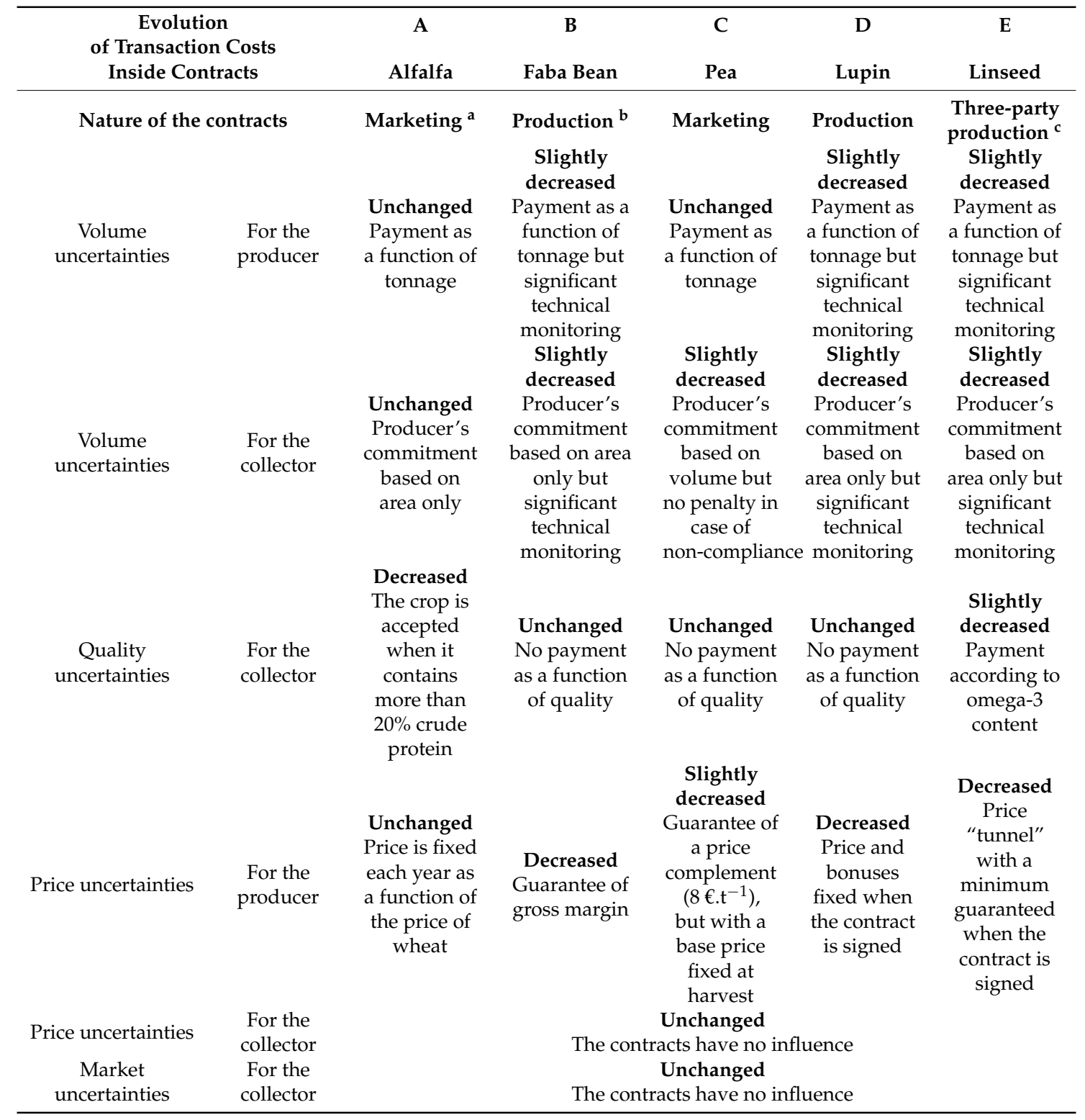

Note: ${ }^{a}$ Marketing contracts specify only selling conditions (e.g., methods for determining prices and amounts, as well as delivery dates and methods). ${ }^{b}$ Production contracts specify only selling conditions and agricultural practices used to influence the final quality of the product (e.g., purchases of specific seeds and pesticides; mandatory operations at specific dates and frequency). ${ }^{c}$ Three-party production contract between the producer, the intermediary that collects and the processor (grouped here as the collector).

\section{Discussion}

This study offers a fresh look at the concomitant and complementary character of two types of costs of producing and marketing crops: opportunity costs and transaction costs. It is focused particularly on diversifying crops—legumes and linseed—which, despite their agronomic advantages, remain relatively underdeveloped in Europe.

Regarding opportunity costs, the database built from the literature review shows that legumes have gross margins similar to those of dominant crops, as long as one examines them at the rotation scale. Regarding transaction costs during exchanges, they seem higher than those of other main crops (such as wheat). They have high specific assets because collectors have to invest greatly in both 
physical and non-physical assets. Additionally, they have relatively high uncertainties in volumes, qualities and prices. Therefore, the results are in line with our first hypothesis (i.e., transaction costs decrease the economic attractiveness of legumes the most).

Our second hypothesis was that contracting can decrease transaction costs and thus promote an increase in legume production. To decrease transaction costs, contracts must decrease uncertainties and secure specific assets. The contracts we studied allow us to conclude that volume uncertainties are (i) only slightly decreased for producers by contracts of Collectors B, D and E and (ii) decreased for Collectors B, C, D and E. Human and physical assets are secured by decrease of volume uncertainties. The largest decrease in uncertainties is in prices for producers, which are decreased by contracts of Collectors B, D and E, due to prices (or gross margins) being partially fixed before harvest. Quality uncertainties are decreased only by Collector A, who accepts only crops with more than $20 \%$ crude protein, and slightly decreased by Collector E. Therefore, the results are also in line with our second hypothesis because contracting can decrease transaction costs, even though this decrease is quite limited. It is interesting to note that the contracts reduce price and volume uncertainties only when collectors engage specific assets. Additionally, to achieve this decrease in uncertainties, production contracts, which aim to decrease volume uncertainties through significant technical monitoring, seem to be more effective than marketing contracts.

Nonetheless, legume contracting is less developed than in the agro-food chain used as a comparison: linseed. Only the contract of linseed implemented by Collector E is able to decrease transaction costs by influencing all characteristics of the transaction costs analyzed. Our results are consistent with those of Charrier et al. [17], who concluded that contracts with guaranteed prices helped increase the spread of diversifying crops such as linseed. In addition, our results for transaction costs were similar to those of the study [28]. Nonetheless, the contracts we studied seem to decrease transaction costs less than those in the sample of the study [28].

The originality of our study lies in different aspects. First, it focuses on legumes (and linseed) produced for animal feed, which differs from most other studies, which focus on legumes produced for human food. Second, it analyzes two types of costs: opportunity costs and transaction costs. Third, it uses different tools: a database built from a literature review of legume gross margins defined a priori or a posteriori and an analysis framework of transaction costs of legumes and linseed, allowing transaction costs to be assessed both outside and inside contracts. One of the main limitations of the study, however, was the small study zone for interviews: surveys were performed only in western France. Although some of these regional collectors have a national reach, it would be interesting to test our hypothesis using a national survey to confirm our conclusions. In addition, we did not have access to details of all the contracts studied. Nonetheless, this approach can be generalized to a larger scale: the analysis frameworks can be transposed to different crops and different agricultural contexts. It also may have been more appropriate to focus solely on production contracts, which seem the best suited to address transaction costs. In-depth analysis of the technical monitoring implemented, related to price formation and added-value creation, would be a promising research approach. Additionally, the studies we analyzed to calculate opportunity costs excluded machinery costs, which can significantly influence crop margins. Our qualitative analysis could also be complemented by more quantitative work that estimates transaction costs directly. Many interviews with farmers and collectors would need to be performed, however, which was not possible with the means at our disposal.

Regarding legume opportunity costs, this study highlights that they are negative or zero if they are calculated in a multi-annual approach at the rotation scale. Nonetheless, calculating them can be tedious, time-consuming and expensive, not only for farmers but for extension agents, who often calculate only annual gross margins for given crops. Substantial resources should thus be provided to disseminate such technico-economic results to farmers. This dissemination could take the form of popular articles or even training sessions for farmers and extension agents. Simple tools could also be developed to ease calculation of multi-annual opportunity costs. Dissemination of these results 
and development of suitable tools could be financed by public or private actors (e.g., extension agents from national or regional governments or from cooperatives).

Regarding legume transaction costs, one of the main costs observed is related to specific investments by collectors. These investments are necessary to increase storage and sorting capacities, even more so if the collector distinguishes crops by quality (e.g., protein content). This result agrees with Reference [23], who identified that volume strategies for grain storage were an obstacle to crop diversification. From these results, it would seem appropriate to develop policies to support investment in storage and sorting infra-collectors, not only at the farm scale (as in the French 2014-2020 "protein plan") but also within cooperatives and other collectors. Such organizational supports, if they are large enough, long term and clearly identified by the actors concerned, would complement well the supports coupled to crop production.

It is important to note that opportunity costs and transaction costs are related to some extent. When crops are seen as a risky production, volume uncertainties are high, which increases transaction costs. Collectors can implement contracts (in particular, production contracts) to decrease uncertainties and thus transaction costs. This decrease in uncertainties can be interpreted as a way to decrease farmers' risk premium associated with the crop. If the risk premium is included in the opportunity cost, we can conclude that a decrease in transaction costs through contracting decreases opportunity costs.

Finally, regarding contracting, Collector E seems to offer the most effective contract for decreasing transaction costs. This is possible by differentiating downstream products in the Bleu-Blanc-Cœur market, which includes products from animals feed linseed whose nutritional qualities (omega-3 and -6 contents) are recognized by consumers. This differentiation of products decreases the substitutability of raw materials used in agricultural production (here, linseeds) and creates added value by tracing the nutritional advantages of these raw materials down to the consumer. More recently, positive impacts on the environment (e.g., decreasing greenhouse gas emissions of ruminants, improving biodiversity) have also appeared as arguments for differentiation within this market. This differentiation of products could also soon lead to non-acceptance of certain raw materials used for animal feed. For example, non-genetically modified (GM) products (e.g., soybean meals in animal feed) are increasingly popular among consumers. Agro-food businesses are diversifying their products to respond to this demand, both in Europe and the United States [56,57]. These new products provide a unique opportunity to develop legumes, which can replace GM soybean meal; however, political and economic questions can arise with non-GM certification [58]. In particular, segregating GM production from non-GM production can be an economic burden for businesses. Contracts thus appear as essential tools for segregating non-GM production in countries that allow GM production [59].

French soybeans, which are non-GM, could also represent an interesting alternative for the non-GM market. They are produced mainly in southwestern France, outside our study zone. Contacts between soybean producers and collectors have been established there. It would thus be interesting to study the different forms of contracts used for French soybeans, and other legumes, to guide development of these crops.

\section{Conclusions}

Despite the agronomic advantages of legumes, their production remains low in Europe. The objective of this study was to analyze how the attractiveness of legumes to farmers could be influenced by two factors: opportunity costs and transaction costs. The opportunity costs of legumes were zero or negative when studied at the scale of the rotation; from an economic viewpoint, rotations with legumes were as good as or better than rotations without them. Transaction costs were higher than those of wheat due to high asset specificity and high uncertainties. The surveys performed in the region did not allow us to conclude that the contracts used sufficiently decrease these transaction costs, in particular because the uncertainties in price remain high in half of the contracts studied. Downstream differentiation seems necessary to decrease transaction costs greatly. Nonetheless, it seems easier to develop downstream differentiation for legumes produced for human food than for animal feed, 
whose added value is diluted in a longer agro-food chain. Policies to disseminate results of opportunity costs and to help collectors invest in storage and sorting tools represent concrete mechanisms for developing the production and marketing of diversifying cultures such as legumes.

Author Contributions: Conceptualization, J.J. and A.R.; methodology, J.J. and A.R.; formal analysis, J.J. and M.C.; investigation, J.J. and A.R.; writing-original draft preparation, J.J., A.R. and M.C.

Funding: This research was co-financed by two French regions, Brittany and the Pays de la Loire, and the European Agricultural Fund for Rural Development 2014-2020 (PEI 16.1), in the project SOS-PROTEIN.

Acknowledgments: The authors thank the students of AGROCAMPUS OUEST who performed the interviews during their final-year project. They also thank Michael Corson for translating the manuscript.

Conflicts of Interest: The authors declare no conflicts of interest. The funders had no role in the design of the study; in the collection, analyses, or interpretation of data; in the writing of the manuscript; or in the decision to publish the results.

\section{References}

1. Kremen, C.; Miles, A. Ecosystem services in biologically diversified versus conventional farming systems: Benefits, externalities, and trade-offs. Ecol. Soc. 2012, 17, 40. [CrossRef]

2. Kennedy, C.M.; Lonsdorf, E.; Neel, M.C.; Williams, N.M.; Ricketts, T.H.; Winfree, R.; Bommarco, R.; Brittain, C.; Burley, A.L.; Cariveau, D.; et al. A global quantitative synthesis of local and landscape effects on wild bee pollinators in agroecosystems. Ecol. Lett. 2013, 16, 584-599. [CrossRef] [PubMed]

3. Gaudin, A.C.M.; Tolhurst, T.N.; Ker, A.P.; Janovicek, K.; Tortora, C.; Martin, R.C.; Deen, W. Increasing crop diversity mitigates weather variations and improves yield stability. PLoS ONE 2015, 10, e0113261. [CrossRef] [PubMed]

4. Lin, B.B. Resilience in agriculture through crop diversification: Adaptive management for environmental change. BioScience 2011, 61, 183-193. [CrossRef]

5. Butault, J.-P.; Dedryver, C.-A.; Gary, C.; Guichard, L.; Jacquet, F.; Meynard, J.M.; Nicot, P.P.; Pitrat, M.; Reau, R.; Sauphanor, B.; et al. Synthèse du Rapport D'étude Écophyto RED: Quelles Voies Pour Réduire L'usage des Pesticides; Ministère de l'Ecologie, de l'Energie, du Développement Durable et de la Mer: Paris, France, 2010.

6. Lechenet, M.; Bretagnolle, V.; Bockstaller, C.; Boissinot, F.; Petit, M.-S.; Petit, S.; Munier-Jolain, N.M. Reconciling pesticide reduction with economic and environmental sustainability in arable farming. PLOS ONE 2014, 9, e97922. [CrossRef]

7. Voisin, A.-S.; Guéguen, J.; Huyghe, C.; Jeuffroy, M.-H.; Magrini, M.-B.; Meynard, J.-M.; Mougel, C.; Pellerin, S.; Pelzer, E. Legumes for feed, food, biomaterials and bioenergy in Europe: A review. Agron. Sustain. Dev. 2014, 34, 361-380. [CrossRef]

8. Cernay, C.; Makowski, D.; Pelzer, E. Preceding cultivation of grain legumes increases cereal yields under low nitrogen input conditions. Environ. Chem. Lett. 2018, 16, 631-636. [CrossRef]

9. Schneider, A.; Huyghe, C. Les Légumineuses pour des Systèmes Agricoles et Alimentaires Durables; Editions Quae: Versailles, France, 2015.

10. Eurostat Crop Production in EU Standard Humidity. Available online: http:/ /appsso.eurostat.ec.europa.eu/ nui/show.do?dataset=apro_cpsh1\&lang=en (accessed on 30 October 2018).

11. Zander, P.; Amjath-Babu, T.S.; Preissel, S.; Reckling, M.; Bues, A.; Schläfke, N.; Kuhlman, T.; Bachinger, J.; Uthes, S.; Stoddard, F.; et al. Grain legume decline and potential recovery in European agriculture: A review. Agron. Sustain. Dev. 2016, 36, 26. [CrossRef]

12. Coase, R.H. The Nature of the Firm. Economica 1937, 4, 386-405. [CrossRef]

13. von Richthofen, J.-S.; Pahl, H.; Bouttet, D.; Casta, P.; Cartrysse, C.; Charles, R.; Lafarga, A. What do European farmers think about grain legumes. Grain Legumes 2006, 14-15.

14. Carof, M.; Godinot, O.; Ridier, A. Diversity of protein-crop management in western France. Agron. Sustain. Dev. 2019. accepted.

15. Cernay, C.; Ben-Ari, T.; Pelzer, E.; Meynard, J.-M.; Makowski, D. Estimating variability in grain legume yields across Europe and the Americas. Sci. Rep. 2015, 5, 11171. [CrossRef] [PubMed]

16. Peltonen-Sainio, P.; Niemi, J.K. Protein crop production at the northern margin of farming: To boost or not to boost. Agric. Food Sci. 2012, 21, 370-383. [CrossRef] 
17. Charrier, F.; Magrini, M.-B.; Charlier, A.; Fares, M.; Le Bail, M.; Messéan, A.; Meynard, J.-M. Alimentation animale et organisation des filières: Une comparaison pois protéagineux-lin oléagineux pour comprendre les facteurs freinant ou favorisant les cultures de diversification. OCL 2013, 20, D407. [CrossRef]

18. David, P.A. Clio and the economics of QWERTY. Am. Econ. Rev. 1985, 75, 332-337.

19. Magrini, M.-B.; Anton, M.; Cholez, C.; Corre-Hellou, G.; Duc, G.; Jeuffroy, M.-H.; Meynard, J.-M.; Pelzer, E.; Voisin, A.-S.; Walrand, S. Why are grain-legumes rarely present in cropping systems despite their environmental and nutritional benefits? Analyzing lock-in in the French agrifood system. Ecol. Econ. 2016, 126, 152-162. [CrossRef]

20. Meynard, J.-M.; Charrier, F.; Fares, M.; Le Bail, M.; Magrini, M.-B.; Charlier, A.; Messéan, A. Socio-technical lock-in hinders crop diversification in France. Agron. Sustain. Dev. 2018, 38, 54. [CrossRef]

21. Williamson, O.E. Transaction-Cost Economics: The Governance of Contractual Relations. J. Law Econ. 1979, 22, 233-261. [CrossRef]

22. Ménard, C. The economics of hybrid organizations. J. Inst. Theor. Econ. 2004, 160, 345-376. [CrossRef]

23. Meynard, J.M.; Messéan, A.; Charrier, F.; Fares, M.; Magrini, M.-B.; Savini, I.; Réchauchère, O. Crop Diversification: Obstacles and Levers. Study of Farms and Supply Chains; INRA: Paris, France, 2013.

24. Bellemare, M.F.; Lim, S. In all shapes and colors: Varieties of contract farming. Appl. Econ. Perspect. Policy 2018, 40, 379-401. [CrossRef]

25. Bouamra-Mechemache, Z.; Duvaleix-Tréguer, S.; Ridier, A. Contrats et modes de coordination en agriculture. Écon. Rural. 2015, 1, 7-28. [CrossRef]

26. Key, N.; McBride, W. Production contracts and productivity in the U.S. hog sector. Am. J. Agric. Econ. 2003, 85, 121-133. [CrossRef]

27. Roussy, C.; Ridier, A.; Chaib, K.; Boyet, M. Marketing contracts and risk management for cereal producers. Agribusiness 2018, 34, 616-630. [CrossRef]

28. Cholez, C.; Magrini, M.-B.; Galliano, D. Les contrats de production en grandes cultures. Coordination et incitations par les coopératives. Économie Rural. 2017, 4, 65-83. [CrossRef]

29. Caplan, D. Management Accounting Concepts and Techniques; Accounting and Law Faculty Books; University at Albany: Albany, NY, USA, 2006.

30. Desbois, D. Méthodologie d'estimation des coûts de production agricole, comparaison de deux méthodes sur le base du RICA. Revue Modulad 2006, 35, 45-72.

31. Carof, M.; Raimbault, J.; Merrien, A.; Leterme, P. Survey of 47 oilseed flax (Linum usitatissimum L.) growers to identify ways to expand its cultivation in France. OCL 2015, 22, D604. [CrossRef]

32. Williamson, O.E. The Mechanisms of Governance; Oxford University Press: Oxford, England, UK, 1996.

33. Terres Inovia. Qualité des Graines de Féverole, Récolte 2017; Terres Inovia: Thiberval-Grignon, France, 2018.

34. Terres Inovia. Qualité des Graines de Pois, Récolte 2017; Terres Inovia: Thiberval-Grignon, France, 2018.

35. Government of Canada. Western Canadian flaxseed-Scientific Analysis of Harvest and Export Quality. Available online: https:/ / www.grainscanada.gc.ca/flax-lin/hqfm-mqrl-eng.htm (accessed on 12 January 2019).

36. FAOstat Producer prices-Monthly. Available online: http://www.fao.org/faostat/en/\#data/PM (accessed on 5 April 2018).

37. FranceAgriMer Grandes Cultures-Informations Économiques-Cotations. Available online: http:// www.franceagrimer.fr/filiere-grandes-cultures/Cereales/Informations-economiques/Chiffres-et-bilans (accessed on 3 June 2018).

38. La Dépêche-Le Petit Meunier Cultures \& Grains-Cotations. Available online: https:/ / www.reussir.info / cultures-grains / cotations (accessed on 4 April 2018).

39. Goodhue, R.E. Food quality: The design of incentive contracts. Annu. Rev. Resour. Econ. 2011, 3, 119-140. [CrossRef]

40. Dequiedt, B.; Moran, D. The cost of emission mitigation by legume crops in French agriculture. Ecol. Econ. 2015, 110, 51-60. [CrossRef]

41. Lötjönen, S.; Ollikainen, M. Does crop rotation with legumes provide an efficient means to reduce nutrient loads and GHG emissions? Rev. Agri. Food Environ. Stud. 2017, 98, 283-312. [CrossRef]

42. Pelzer, E.; Bourlet, C.; Carlsson, G.; Lopez-Bellido, R.J.; Jensen, E.S.; Jeuffroy, M.-H. Design, assessment and feasibility of legume-based cropping systems in three European regions. Crop Pasture Sci. 2017, 68, 902-914. [CrossRef] 
43. Bridet-Guillaume, F.; Millot, D.; Buitink, J.; Gueguen, J.; Jeuffroy, M.-H.; Le Gall, M.; Munier-Jolain, N.; Tivoli, B.; Duc, G. Analyse bibliométrique des publications scientifiques françaises et mondiales sur les protéagineux au cours de la période 2000-2009: Comparaison au soja et aux espèces modèles. Innov. Agron. 2010, 11, 137-145.

44. Preissel, S.; Reckling, M.; Schläfke, N.; Zander, P. Magnitude and farm-economic value of grain legume pre-crop benefits in Europe: A review. Field Crops Res. 2015, 175, 64-79. [CrossRef]

45. Ridier, A.; Chaib, K.; Roussy, C. A Dynamic Stochastic Programming model of crop rotation choice to test the adoption of long rotation under price and production risks. Eur. J. Oper. Res. 2016, 252, 270-279. [CrossRef]

46. Martin, A.; Kucab, L.; Bressand, M.; Colbert, E.; Le Jeune, C.; Montrone, E. Accroître l'autonomie protéique, quels enjeux pour la France et la Bretagne dans l'UE? Quelle faisabilité pour les exploitations d'Ille-et-Vilaine; Agrocampus Ouest: Rennes, France, 2014.

47. Xing, H.; Liu, D.L.; Li, G.; Wang, B.; Anwar, M.R.; Crean, J.; Lines-Kelly, R.; Yu, Q. Incorporating grain legumes in cereal-based cropping systems to improve profitability in southern New South Wales, Australia. Agric. Syst. 2017, 154, 112-123. [CrossRef]

48. Carrouée, B.B.; Schneider, A.A.; Flénet, F.F.; Jeuffroy, M.-H.M.-H.; Nemecek, T.T. Introduction du pois protéagineux dans des rotations à base de céréales à paille et colza: Impacts sur les performances économiques et environnementales. Innov. Agron. 2012, 25, 125-142.

49. Reckling, M.; Bergkvist, G.; Watson, C.A.; Stoddard, F.L.; Zander, P.M.; Walker, R.L.; Pristeri, A.; Toncea, I.; Bachinger, J. Trade-offs between economic and environmental impacts of introducing legumes into cropping systems. Front. Plant Sci. 2016, 7, 669. [CrossRef] [PubMed]

50. Hirth, J.R.; Haines, P.J.; Ridley, A.M.; Wilson, K.F. Lucerne in crop rotations on the Riverine Plains. 2. Biomass and grain yields, water use efficiency, soil nitrogen, and profitability. Aust. J. Agric. Res. 2001, 52, 279-293. [CrossRef]

51. von Richthofen, J.-S.; Pahl, H.; Casta, P.; Dubois, G.; Lafarga, A.; Nemecek, T.; Pedersen, J.B. Economic impact of grain legumes in European crop rotations. Grain Legumes 2006, 45, 16-19.

52. Froidmont, E.; Bartiaux-Thill, N. Suitability of lupin and pea seeds as a substitute for soybean meal in high-producing dairy cow feed. Anim. Res. 2004, 53, 475-487. [CrossRef]

53. Jezierny, D.; Mosenthin, R.; Bauer, E. The use of grain legumes as a protein source in pig nutrition: A review. Anim. Feed Sci. Technol. 2010, 157, 111-128. [CrossRef]

54. Schilizzi, S.; Pannell, D.J. The economics of nitrogen fixation. Agronomie 2001, 21, 527-537. [CrossRef]

55. Jouan, J.; Ridier, A.; Carof, M. SYNERGY: A bio economic model assessing the economic and environmental impacts of increased regional protein self-sufficiency. In Proceedings of the 166th EAAE Seminar on Sustainability in the Agri-Food Sector, Galway, Ireland, 30-31 August 2018.

56. Bain, C.; Dandachi, T. Governing GMOs: The (counter) movement for mandatory and voluntary non-GMO labels. Sustainability 2014, 6, 9456-9476. [CrossRef]

57. Castellari, E.; Soregaroli, C.; Venus, T.J.; Wesseler, J. Food processor and retailer non-GMO standards in the US and EU and the driving role of regulations. Food Policy 2018, 78, 26-37. [CrossRef]

58. McCluskey, J.J.; Wesseler, J.; Winfree, J.A. The economics and politics GM food labeling: An introduction to the special issue. Food Policy 2018, 78, 1-5. [CrossRef]

59. Sykuta, M.; Parcell, J. Contract structure and design in identity-preserved soybean production. Appl. Econ. Perspect. Policy 2003, 25, 332-350. [CrossRef]

(C) 2019 by the authors. Licensee MDPI, Basel, Switzerland. This article is an open access article distributed under the terms and conditions of the Creative Commons Attribution (CC BY) license (http://creativecommons.org/licenses/by/4.0/). 